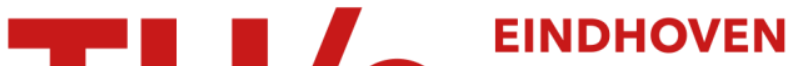 UNIVERSITY OF TECHNOLOGY
}

\section{ESR studies on hydrodesulfurization catalysts: supported and unsupported sulfided molybdenum and tungsten catalysts}

Citation for published version (APA):

Konings, A. J. A., van Dooren, A. M., Koningsberger, D. C., Beer, de, V. H. J., Farragher, A. L., \& Schuit, G. C. A. (1978). ESR studies on hydrodesulfurization catalysts: supported and unsupported sulfided molybdenum and tungsten catalysts. Journal of Catalysis, 54(1), 1-12. https://doi.org/10.1016/0021-9517\%2878\%2990021-0, https://doi.org/10.1016/0021-9517(78)90021-0

DOI:

10.1016/0021-9517\%2878\%2990021-0

10.1016/0021-9517(78)90021-0

Document status and date:

Published: 01/01/1978

\section{Document Version:}

Publisher's PDF, also known as Version of Record (includes final page, issue and volume numbers)

\section{Please check the document version of this publication:}

- A submitted manuscript is the version of the article upon submission and before peer-review. There can be important differences between the submitted version and the official published version of record. People interested in the research are advised to contact the author for the final version of the publication, or visit the $\mathrm{DOI}$ to the publisher's website.

- The final author version and the galley proof are versions of the publication after peer review.

- The final published version features the final layout of the paper including the volume, issue and page numbers.

Link to publication

\section{General rights}

Copyright and moral rights for the publications made accessible in the public portal are retained by the authors and/or other copyright owners and it is a condition of accessing publications that users recognise and abide by the legal requirements associated with these rights.

- Users may download and print one copy of any publication from the public portal for the purpose of private study or research.

- You may not further distribute the material or use it for any profit-making activity or commercial gain

- You may freely distribute the URL identifying the publication in the public portal.

If the publication is distributed under the terms of Article 25fa of the Dutch Copyright Act, indicated by the "Taverne" license above, please follow below link for the End User Agreement:

www.tue.nl/taverne

Take down policy

If you believe that this document breaches copyright please contact us at:

openaccess@tue.nl

providing details and we will investigate your claim. 


\title{
ESR Studies on Hydrodesulfurization Catalysts: Supported and Unsupported Sulfided Molybdenum and Tungsten Catalysts
}

\author{
A. J. A. Konings, ${ }^{*}$ A. M. van Dooren, ${ }^{*}$ D. C. Koningsberger, ${ }^{*}$ V. H. J. de Beer, ${ }^{*}$ \\ A. L. Farragher, $\dagger$ and G. C. A. Schuit* \\ * Laboratory for Inorganic Chemistry and Catalysis, Eindhoven University of Technology, \\ Eindhoven, and †Koninklijke/Shell-Laboratorium (Shell Research B. V.), \\ Amsterdam, The Netherlands
}

Received April 20, 1977; revised November 9, 1977

\begin{abstract}
Five different signals have been analyzed in ESR spectra obtained from sulfided molybdenum- or tungsten-containing catalyst samples. Signal I (oxo- $\mathrm{Mo}^{5+}, g=1.933$ for $\mathrm{Mo} / \gamma-\mathrm{Al}_{2} \mathrm{O}_{3}$; and oxo- $\mathrm{W}^{5+}, g=1.78$ for $\mathrm{W} / \gamma-\mathrm{Al}_{2} \mathrm{O}_{3}$ ), and possibly signal III arise as a result of interactions with the support. Signal II $\left(g=1.985\right.$ for $\mathrm{Mo} / \mathrm{SiO}_{2}$, and $g=1.91$ for $\left.\mathrm{W} / \gamma-\mathrm{Al}_{2} \mathrm{O}_{3}\right)$ and signal IV ( $g=1.995$ for $\mathrm{W} / \gamma-\mathrm{Al}_{2} \mathrm{O}_{3}$, and $g=2.01$ for $\mathrm{WS}_{2}$ bulk) have been detected both on supported and on unsupported sulfided samples. These two signals show a complementary behavior upon evacuation and $\mathrm{H}_{2} \mathrm{~S}$ adsorption and are therefore ascribed to paramagnetic surface species in the $\mathrm{MoS}_{2}$ and $\mathrm{WS}_{2}$ phases. Some surface configurations are proposed to describe the origin of these paramagnetic surface species. The origin of signal $V$ which has been detected in supported and unsupported samples is still unknown.
\end{abstract}

\section{INTRODUCTION}

For the study of the structure of active sites on heterogeneous catalysts, techniques are required which are sensitive to details on an atomic scale. When the active sites contain paramagnetic species, electron spin resonance (ESR) may satisfy this condition. This technique has the advantage of being sensitive enough to be able to measure the usually low concentration of the active sites. Voorhoeve (1) demonstrated the use of ESR in his study of $\mathrm{Ni}-\mathrm{W}$ sulfided supported and unsupported catalysts. He reported a correlation between the benzene hydrogenation activity and the intensity of an ESR signal ascribed to $\mathrm{W}^{3+}$ ions. He did not report any details of the ESR signal nor did he report a study of the analogous (2-8) Co-Mo system. The purpose of the present paper is to present the ESR results on supported as well as un- supported molybdenum- or tungstencontaining catalysts. It forms part of a general study with the objective of obtaining more insight into the atomic structure of $\mathrm{Ni}(\mathrm{Co})-\mathrm{W}(\mathrm{Mo})$ hydrodesulfurization (HDS) catalysts. By studying the influence of evacuation, $\mathrm{H}_{2} \mathrm{~S}$, and thiophene treatments on freshly sulfided samples, five different ESR signals have been distinguished. Some signals are interpreted in terms of surface $\mathbf{M}^{n+} \mathbf{S}_{x}$ configurations. This work also demonstrates the necessity of in situ measurements on sulfided catalysts.

\section{EXPERIMENTAL}

All materials used were free from paramagnetic impurities.

Supported catalysts. $\mathrm{SiO}_{2}$ (Ketjen F-2) was washed with excess ammonia $(4.5 \mathrm{~N})$ and then with distilled water. After drying 


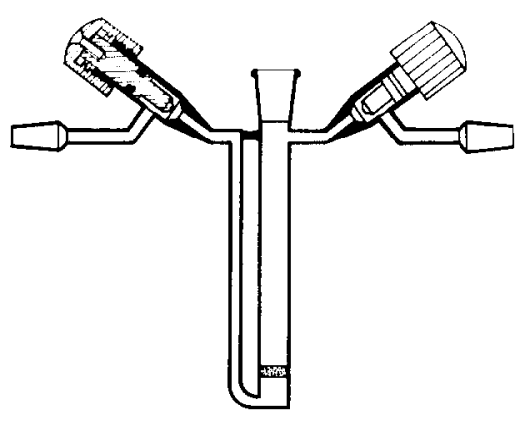

FIG. 1. ESR sulfiding reactor.

at $110^{\circ} \mathrm{C}$ for $12 \mathrm{hr}$ it was calcined in air for $2.5 \mathrm{hr}$ at $600^{\circ} \mathrm{C}$. The pore volume was $1.05 \mathrm{~cm}^{3} \mathrm{~g}^{-1} \cdot \gamma-\mathrm{Al}_{2} \mathrm{O}_{3}$ was prepared by calcining boehmite (Martinswerk $\mathrm{GmbH}$ $\mathrm{RH6}$ ) in air for $2 \mathrm{hr}$ at $600^{\circ} \mathrm{C}$, resulting in a pore volume of $0.35 \mathrm{~cm}^{3} \mathrm{~g}^{-1}$. Analyticalgrade ammonium heptamolybdate (AHM) (Merck) and ammonium metatungstate (AMW) (Koch-Light Laboratories, Ltd.) were used.

Catalysts containing $12 \% \quad \mathrm{MoO}_{3}$ or $19.3 \%(\mathrm{w} / \mathrm{w}) \quad \mathrm{WO}_{3}$ were prepared by impregnating a support with AHM or AMW dissolved in a volume of water corresponding to the pore volume of the support, drying at $110^{\circ} \mathrm{C}$ for $12 \mathrm{hr}$, and calcining for $2 \mathrm{hr}$ at 450 and $600^{\circ} \mathrm{C}$ for $\mathrm{SiO}_{2}$ and $\gamma-\mathrm{Al}_{2} \mathrm{O}_{3}$ supports, respectively.

Unsupported catalysts. Bulk catalysts with a high specific surface area were prepared via thermal decomposition of the corresponding ammonium thio compounds (9, 10). Ammonium thiomolybdate and ammonium thiotungstate were prepared from AHM and $\mathrm{H}_{2} \mathrm{WO}_{4}$, respectively (11, 12), and were decomposed to the corresponding disulfides by heating to $400^{\circ} \mathrm{C}$ for $6 \mathrm{hr}$ at $10^{-4}$ Torr. The disulfides obtained were identified by X-ray diffraction $(9,10)$. The specific surface areas were $16 \mathrm{~m}^{2} \mathrm{~g}^{1}$ for $\mathrm{MoS}_{2}$ and $57 \mathrm{~m}^{2} \mathrm{~g}^{-1}$ for $\mathrm{WS}_{2}$.

Sulfidation and sample treatments. All samples were sulfided under continuousflow conditions $\left(\mathrm{H}_{2}\right.$ containing $16 \%(\mathrm{v} / \mathrm{v})$ $\mathrm{H}_{2} \mathrm{~S}, 50 \mathrm{~cm}^{3} \mathrm{~min}^{-1}, 2$ or $24 \mathrm{hr}, 400^{\circ} \mathrm{C}$ ). The samples were cooled from $400^{\circ} \mathrm{C}$ to room temperature $\left(10 \mathrm{~min}\right.$ ) in the same $\mathrm{H}_{2} / \mathrm{H}_{2} \mathrm{~S}$ flow and then were flushed with helium (50 $\mathrm{cm}^{3} \mathrm{~min}^{-1}, 10 \mathrm{~min}$ ).

In order to prevent contamination of the sample by oxygen, which complicates the ESR analysis, a special sulfiding reactor was used (see Fig. 1). Hydrogen and helium were deoxygenated over BTS catalyst (BASF R 3-11) and dried over molecular sieves (Union Carbide 4A). Hydrogen sulfide (Matheson, CP grade) was used as supplied.

Table 1 lists the (pre)treatments applied. All treatments were carried out with a 200-mg catalyst sample. The thiophene saturation system used has been described earlier (13).

ESR measurements. The ESR measurements were carried out with a Varian E-15

TABLE 1

Specifications of Sample Treatments

\begin{tabular}{clcr}
\hline No. & \multicolumn{1}{c}{ Treatment } & $\begin{array}{c}\text { Temperature } \\
\left({ }^{\circ} \mathrm{C}\right)\end{array}$ & $\begin{array}{r}\text { Time } \\
(\mathrm{min})\end{array}$ \\
\hline 1 & $\mathrm{H}_{2}$ with $16 \%(\mathrm{v} / \mathrm{v}) \mathrm{H}_{2} \mathrm{~S}\left(50 \mathrm{~cm}^{3} \mathrm{~min}^{-1}\right)$ & 400 & 120 \\
2 & $\mathrm{H}_{2}$ with $16 \%(\mathrm{v} / \mathrm{v}) \mathrm{H}_{2} \mathrm{~S}\left(50 \mathrm{~cm}^{3} \mathrm{~min}^{-1}\right)$ & 400 & 1440 \\
3 & $\mathrm{H}_{2}\left(50 \mathrm{~cm}^{3} \mathrm{~min}^{-1}\right)$ & 400 & 5 \\
4 & Contact with air for 15 min ; heating & 200 & 5 \\
5 & Evacuation at $10^{-3}$ Torr & 400 & 10 \\
6 & He with $16 \%(\mathrm{v} / \mathrm{v}) \mathrm{H}_{2} \mathrm{~S}\left(50 \mathrm{~cm}^{3} \mathrm{~min}^{-1}\right)$ & 400 & 30 \\
7 & He with $7 \%(\mathrm{v} / \mathrm{v}) \mathrm{C}_{4} \mathrm{H}_{4} \mathrm{~S}\left(50 \mathrm{~cm}^{3} \mathrm{~min}^{-1}\right)$ & 150 & 15 \\
\hline
\end{tabular}




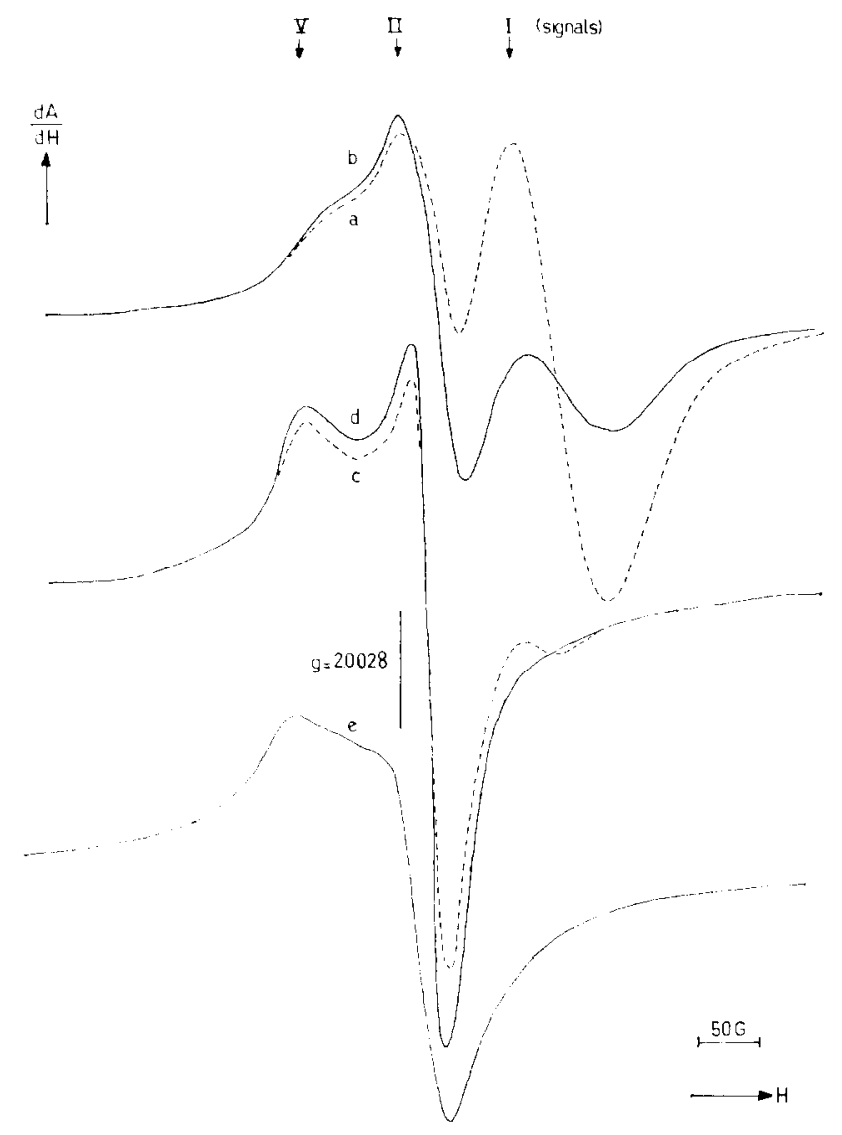

FIG. 2. ESR spectra: (a) $\mathrm{Mo} / \gamma-\mathrm{Al}_{2} \mathrm{O}_{3}$, sulfidation for $2 \mathrm{hr}$ (1); (b) $\mathrm{Mo} / \gamma-\mathrm{Al}_{2} \mathrm{O}_{3}$ sulfidation for $24 \mathrm{hr}$ (2); (c) $\mathrm{Mo} / \mathrm{SiO}_{2}$, sulfidation for $2 \mathrm{hr}$ (1); (d) $\mathrm{Mo} / \mathrm{SiO}_{2}$, sulfidation for $24 \mathrm{hr}$ (2); (e) $\mathrm{MoS}_{2}$ bulk, sulfidation for $2 \mathrm{hr}$ (1).

Figs. 2-7. The numbers within parentheses correspond to the sample treatments specified in Table 1.

ESR spectrometer equipped with a TE 104 dual-sample cavity. A Varian strong-pitch sample was used to calibrate $(g=2.0028)$ the magnetic field and as a standard for the quality factor of the ESR cavity (i.e., sensitivity). Relative signal intensities can be calculated with an accuracy of about $10 \%$. Unless otherwise indicated, all measurements were carried out at room temperature using $100-\mathrm{mW}$ microwave power and a microwave frequency of about 9.15 $\mathrm{GHz}$. Some ESR spectra were measured at 4.2 or $20^{\circ} \mathrm{K}$. To obtain this temperature the TE 104 ESR cavity was equipped with a liquid helium continuous-flow cryostat (Oxford Instruments).

\section{RESULTS}

Five different ESR signals can be distinguished in both molybdenum- and tungsten-containing catalysts. These signals are designated by $I-V$. The ESR signals are indicated in the corresponding figures by the approximate position of their low-field peaks, since especially the lowfield peaks of these signals could be clearly detected separately. The $g$ values are determined at the turning points.

\section{Signal I}

Figures $2 a$ and $b$ show the ESR spectra obtained from $\mathrm{Mo} / \gamma-\mathrm{Al}_{2} \mathrm{O}_{3}$ samples which 


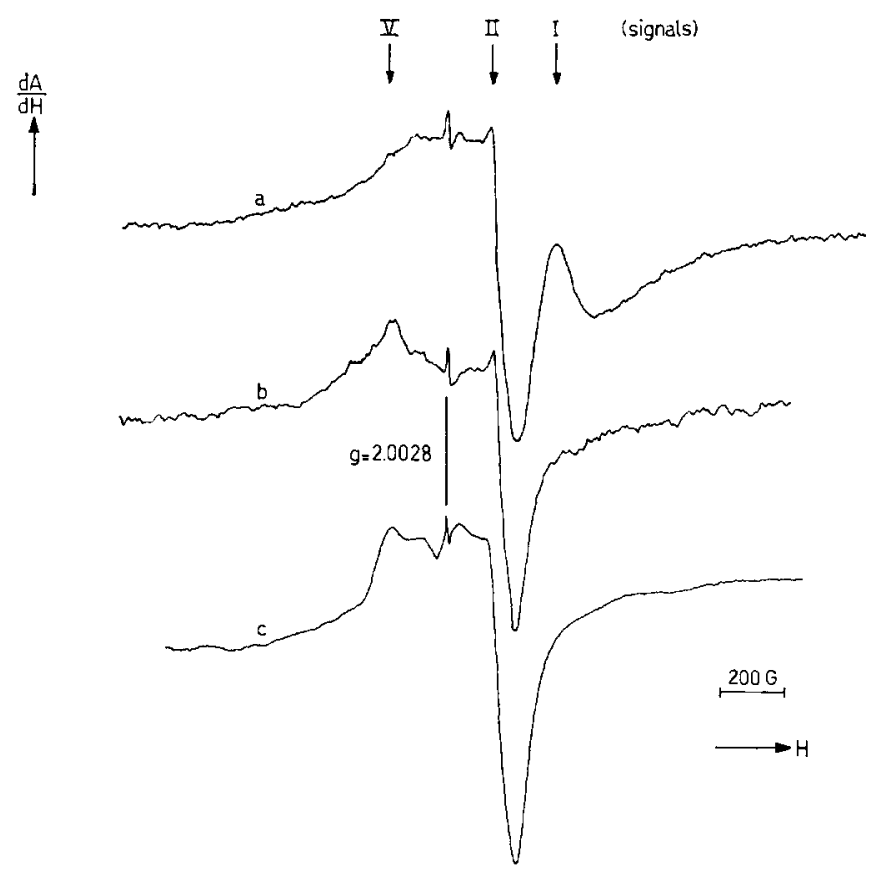

FIG. 3. ESR spectra: (a) W/ $\gamma-\mathrm{Al}_{2} \mathrm{O}_{3}$, sulfidation for $2 \mathrm{hr}$ (1); (b) $\mathrm{W} / \mathrm{SiO}_{2}$, sulfidation for $2 \mathrm{hr}$ (1); (c) $\mathrm{WS}_{2}$ bulk, sulfidation for $2 \mathrm{hr}$ (1). The ESR measurements on the supported tungsten samples were carricd out at $20^{\circ} \mathrm{K}$.

have been sulfided for 2 and $24 \mathrm{hr}$, respectively. The intensity of signal I $(g=1.933)$ decreases with increasing time of sulfiding. In Fig. 2c the ESR spectrum of $\mathrm{Mo} / \mathrm{SiO}_{2}$ after sulfiding for $2 \mathrm{hr}$ is shown. It is apparent that signal $\mathrm{I}$ on $\mathrm{SiO}_{2}$ has a low intensity compared to the $\gamma-\mathrm{Al}_{2} \mathrm{O}_{3}$-supported sample and is not observable in the 24-hr sulfided sample (Fig. 2d). Signal I is absent in bulk $\mathrm{MoS}_{2}$ (Fig. 2e).

As shown in Fig. 3, tungsten-based catalysts show an analogous behavior. Note that the scan range of the magnetic field is now four times larger than was used in Fig. 2. A signal with $g=1.78$ is observable after $2 \mathrm{hr}$ of sulfiding on $\mathrm{W} / \gamma-\mathrm{Al}_{2} \mathrm{O}_{3}$ (Fig. $3 a$ and is not observed in $\mathrm{W} / \mathrm{SiO}_{2}$ or bulk $\mathrm{WS}_{2}$.

\section{Signals II and V}

The low-field part of the spectra of Figs. 2 and 3 shows the presence of other ESR signals. In Fig. 2 the ESR spectrom- eter sensitivity has been adjusted to allow for differences in sample density so that spectra $a-d$ show the relative signal intensity per molybdenum atom. The same procedure has been followed for the supported tungsten samples shown in Fig. 3. The strongest ESR absorption (II) occurs at $g$ values of about 1.985 and 1.91 for the molybdenum- and tungsten-containing samples, respectively. Although the overall $g$ values are different, the results shown in Figs. 2 and 3 for the molybdenum- and tungsten-based catalysts are essentially the same.

Signal II is observable with all samples, whereas peak $\mathrm{V}$ is relatively weak from $\gamma-\mathrm{Al}_{2} \mathrm{O}_{3}$-supported samples. The question arises whether peaks II and $\mathrm{V}$ originate from two different paramagnetic sites or from one paramagnetic site with axial symmetry (2 $g$-value signal). The line shapes of the ESR spectra obtained from the $\mathrm{SiO}_{2}$-supported and bulk samples suggest the latter possibility. 
In order to investigate this, ESR microwave saturations experiments were carried out on a sulfided $\mathrm{SiO}_{2}$-supported molybdenum catalyst. The experiments were performed at $4.2^{\circ} \mathrm{K}$. As is shown in Fig. $4 \mathrm{~b}$, signal II is more prone to saturation than signal V. Similarly, reduction with hydrogen $\left(50 \mathrm{~cm}^{3} \mathrm{~min}^{-1}, T=400^{\circ} \mathrm{C}, t=10 \mathrm{~min}\right)$ of a sulfided $\mathrm{Mo} / \mathrm{SiO}_{2}$ sample causes a larger decrease in intensity for signal II than for signal V. Signal V can now be detected almost separately (see Fig. 4c).

The influence of oxygen is shown in Fig. 4d. After sulfidation and cooling down to room temperature, the ESR sulfiding reactor was opened to the air for $15 \mathrm{~min}$ and then heated for $5 \mathrm{~min}$ at $T=200^{\circ} \mathrm{C}$.
It is seen in Fig. $4 d$ that signal II disappeared nearly completely. A $3 g$-value signal $\left(g_{1}=2.048, \quad g_{2}=2.029\right.$, and $g_{3}$ $=1.998$ ) is now superimposed on signal $\mathrm{V}$. These experiments clearly show that peaks II and $V$ originate from two different paramagnetic sites with different relaxation behavior and different reactivity toward hydrogen and oxygen treatments.

The oxygen treatment demonstrates the necessity for carrying out ESR measurements on sulfided catalysts in situ. Even a small amount of air at room temperature without the further heating applied in Fig. $4 \mathrm{~d}$ causes a significant change in the ESR spectrum of supported sulfided catalysts.

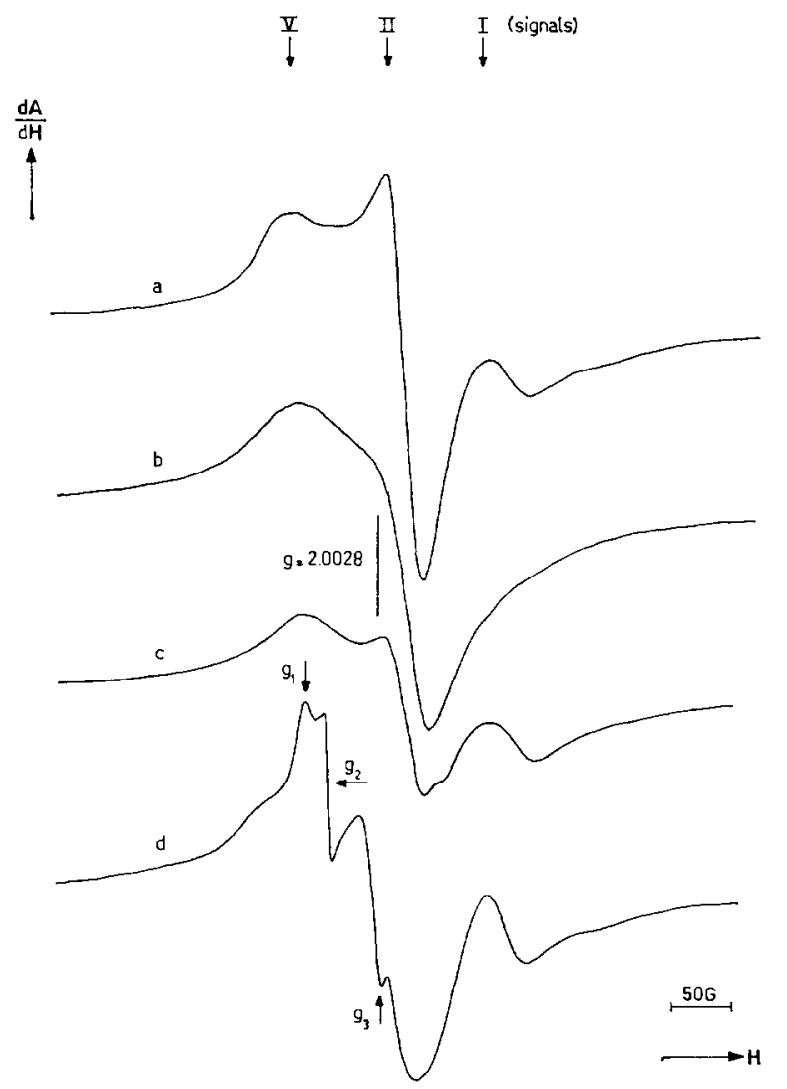

Fig. 4. ESR spectra: (a) $\mathrm{Mo}_{0} / \mathrm{SiO}_{2}$, sulfidation for $2 \mathrm{hr}$ (1); (b) $\mathrm{Mo} / \mathrm{SiO}_{2}$, sulfidation for $2 \mathrm{hr}$ (1) and microwave saturation $\left(200 \mathrm{~mW}\right.$ at $\left.4.2^{\circ} \mathrm{K}\right)$; (c) $\mathrm{Mo} / \mathrm{SiO}_{2}$, sulfidation for $2 \mathrm{hr}$ (1) and reduction with $\mathrm{H}_{2}$ (3); (d) $\mathrm{Mo} / \mathrm{SiO}_{2}$ sulfidation for $2 \mathrm{hr}$ (1) and treatment in air (4). 

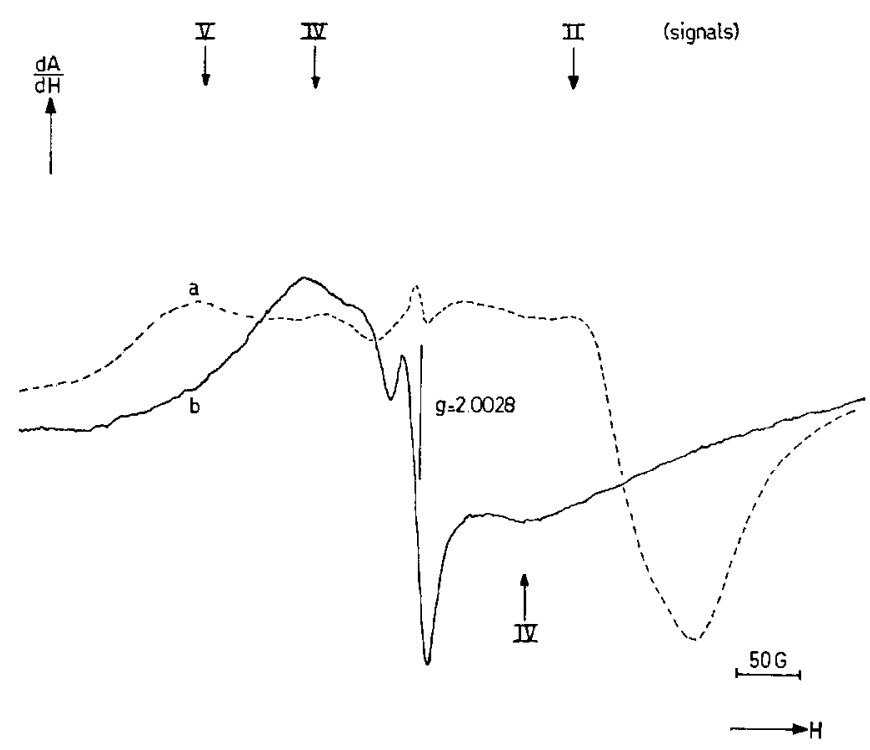

Fig. 5. ESR spectra: (a) $\mathrm{WS}_{2}$ bulk, sulfidation for $2 \mathrm{hr}$ (1); (b) $\mathrm{WS}_{2}$ bulk, sulfidation for $2 \mathrm{hr}$ (1) and evacuation (5). The dial settings on the ESR spectrometer for the dotted and solid curves are the same.

\section{Signal IV}

Signal IV is the least readily discernible of the ESR peaks. Its presence is most clearly demonstrated when bulk $\mathrm{WS}_{2}$ is subjected to an evacuation treatment $\left(10^{-3}\right.$ Torr, $400^{\circ} \mathrm{C}, 10 \mathrm{~min}$ ) as shown in Figs. $5 \mathrm{a}$ and $b$. The spectrum in Fig. 5a (which is in fact the spectrum in Fig. 3c, but is now shown on the smaller scan range used for Mo-containing samples) illustrates the ESR signals after sulfidation. Figure $5 \mathrm{~b}$ gives the results after evacuation. Signals II and V clearly disappear, leaving a new signal (IV, $g=2.01, \Delta H=180 \mathrm{G}$ ).

Figure 6 shows the results of the evacuation treatment when applied to $\mathrm{Mo} / \mathrm{\gamma}$ $\mathrm{Al}_{2} \mathrm{O}_{3}, \mathrm{Mo} / \mathrm{SiO}_{2}$, and bulk $\mathrm{MoS}_{2}$ samples. In all cases signal II is reduced in intensity and the turning point moves to a higher $g$ value $(\Delta g=0.01)$. This change cannot be explained on the basis of a change in the relative contributions of signals II and $V$ since, as is apparent from Fig. 4 (spectra b and $c$ ), both signals have approximately the same $g$ value. The data therefore suggest a new signal (IV) for which the $g$ value and linewidth are most readily evaluated from Fig. 6b ( $g=1.995, \Delta H=68 \mathrm{G})$.

The bulk samples of $\mathrm{MoS}_{2}$ and $\mathrm{WS}_{2}$ also develop a weak, sharp signal near the free spin value of $g=2.0023$ upon evacuation.

\section{Signal III}

This ESR signal can be detected only on sulfided molybdenum-supported catalysts after adsorption of $\mathrm{H}_{2} \mathrm{~S}$ or thiophene. The influence of thiophene was studied on sulfided $\mathrm{Mo} / \mathrm{SiO}_{2}$ by exposing this sample at $150^{\circ} \mathrm{C}$ to thiophene-saturated helium gas (He containing $7 \%(\mathrm{v} / \mathrm{v})$ thiophene, $50 \mathrm{~cm}^{3}$ $\left.\min ^{-1}, 15 \mathrm{~min}\right)$. An ESR spectrum was produced and is shown in Fig. 7c. The highfield part of this spectrum definitely shows the occurrence of a new peak (peak III). The intensity of the original peak II is increased after the thiophene treatment.

Adsorption of $\mathrm{H}_{2} \mathrm{~S}$ was carried out by treating a sulfided $\mathrm{Mo} / \mathrm{SiO}_{2}$ sample at $400^{\circ} \mathrm{C}$ with a mixture of $16 \% \quad \mathrm{H}_{2} \mathrm{~S}$ in helium for $30 \mathrm{~min}$. Figure $7 \mathrm{~b}$ shows the presence of the new signal III and also an increase in intensity of signal II. The ratio 
intensity II/intensity III seems to be larger after the adsorption of $\mathrm{H}_{2} \mathrm{~S}$ than after treatment with thiophene (cf. highfield wings). This result combined with the fact that the turning point of the overall ESR spectrum after adsorption of thiophene is slightly different $(\Delta g=0.003)$ from the corresponding turning point after $\mathrm{H}_{2} \mathrm{~S}$ treatment leads to the conclusion that the $g$ value for peak III is slightly greater than that for peak II. Recording the ESR spectrum of the $\mathrm{H}_{2} \mathrm{~S} / \mathrm{He}$-treated sulfided $\mathrm{Mo} / \mathrm{SiO}_{2}$ sample with a tenfold higher amplification reveals a weak hyperfine structure of molybdenum ( $I=\frac{5}{2}$, six lines).

Treating sulfided $\mathrm{Mo} / \gamma-\mathrm{Al}_{2} \mathrm{O}_{3}$ with $\mathrm{H}_{2} \mathrm{~S}$ under the same conditions as for the sul- fided $\mathrm{Mo} / \mathrm{SiO}_{2}$ sample results in a smaller increase in peak II intensity and a weaker peak III. $\mathrm{H}_{2} \mathrm{~S}$ treatment of bulk samples $\left(\mathrm{MoS}_{2}, \mathrm{WS}_{2}\right)$ and sulfided supported tungsten catalysts did not result in any increase of peak II or in the occurrence of peak III.

\section{DISCUSSION}

It is widely accepted in the literature $(14-16)$ that reduction of supported oxidic molybdenum catalysts leads to the formation of $\mathrm{Mo}^{5+}$ ions, which can be detected by ESR. The $g$ values obtained for signal I are within the limits of accuracy similar to the $g$ values obtained in the literature for oxo-Mo ${ }^{5+}$ ions. Moreover, our results

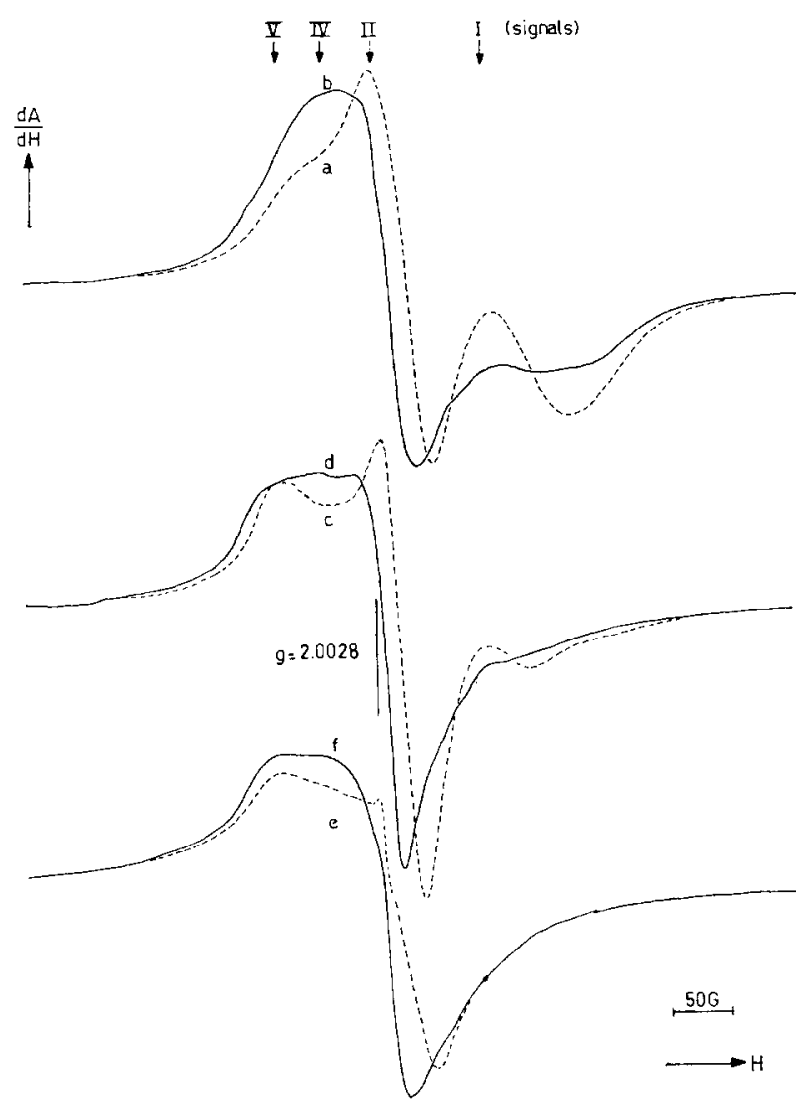

Fig. 6. ESR spectra : (a) $\mathrm{Mo} / \gamma-\mathrm{Al}_{2} \mathrm{O}_{3}$, sulfidation for $24 \mathrm{hr}$ (2); (b) $\mathrm{Mo} / \gamma-\mathrm{Al}_{2} \mathrm{O}_{3}$, sulfidation for $24 \mathrm{hr}$ (2) and evacuation (5); (c) $\mathrm{Mo} / \mathrm{SiO}_{2}$, sulfidation for $2 \mathrm{hr}$ (1); (d) $\mathrm{Mo} / \mathrm{SiO}_{2}$, sulfidation for $2 \mathrm{hr}$ (1) and evacuation (5); (e) Mos $\mathrm{S}_{2}$ bulk, sulfidation for $2 \mathrm{hr}$ (1); (f) Mos 2 bulk, sulfidation for $2 \mathrm{hr}$ (1) and evacuation (5). The dial settings on the FsR spectrometer for the dotted and solid curves are the same. 


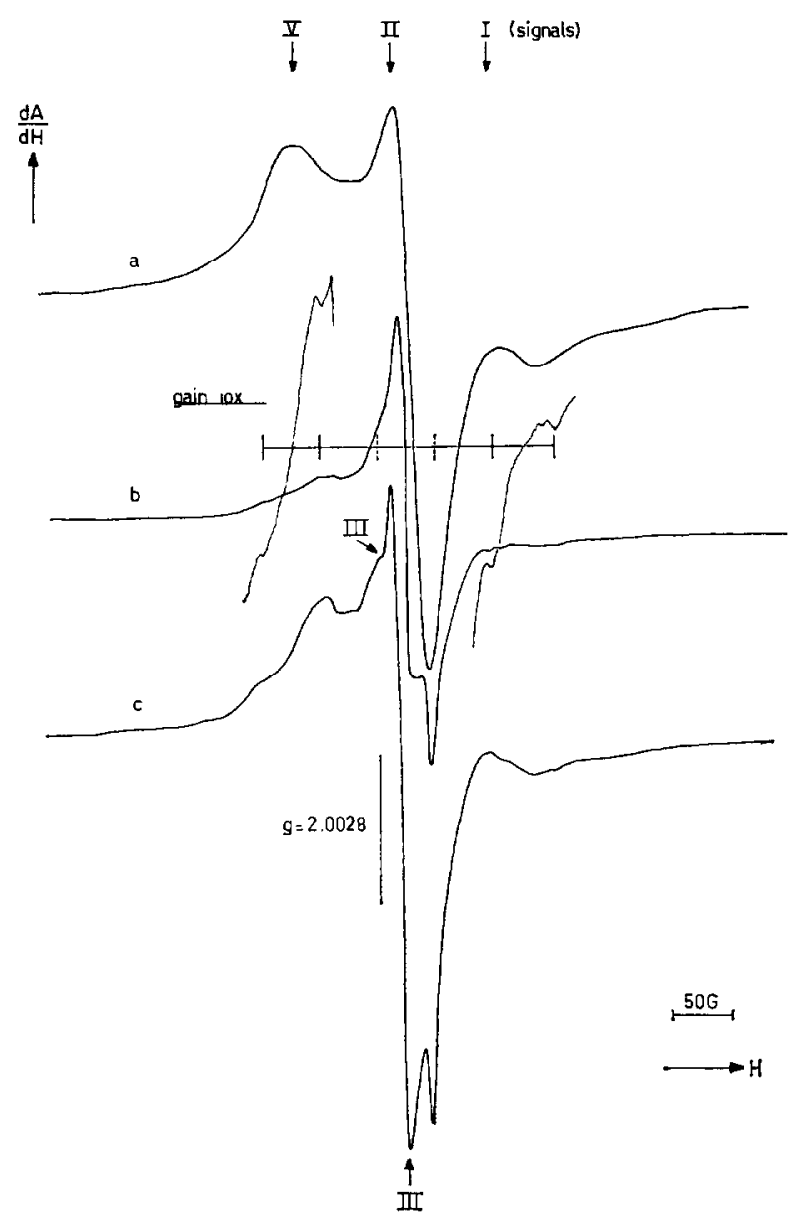

Fia. 7. ESR spectra: (a) $\mathrm{Mo} / \mathrm{SiO}_{2}$, sulfidation for $2 \mathrm{hr}$ (1) (Gain $2 \times 10^{2}$ ) ; (b) $\mathrm{Mo} / \mathrm{SiO}_{2}$, sulfidation for $2 \mathrm{hr}$ (1) and treatment with $\mathrm{H}_{2} \mathrm{~S}$ (6) (gain $1.25 \times 10^{2}$ ); (c) $\mathrm{Mo} / \mathrm{SiO}_{2}$, sulfidation for $2 \mathrm{hr}$ (1) and treatment with $\mathrm{C}_{4} \mathrm{H}_{4} \mathrm{~S}(7)$ (gain $5 \times 10^{1}$ ).

are in agreement with the assignment of signal I to oxo- $\mathrm{Mo}^{5+}$ species, viz.: (i) signal $\mathrm{I}$ is not detected on bulk $\mathrm{MoS}_{2}$; (ii) less paramagnetic oxo-Mo species are preserved on the surface of $\mathrm{SiO}_{2}$ after sulfiding than for $\gamma-\mathrm{Al}_{2} \mathrm{O}_{3}$ as result of the greater interaction of $\mathrm{Mo}^{5+}$ with $\gamma-\mathrm{Al}_{2} \mathrm{O}_{3}$ than with $\mathrm{SiO}_{2},(17-22)$; (iii) the intensity of signal I decreases with increasing time of sulfidation (conversion of oxo-Most into oxo-sulfo$\mathrm{Mo}^{n+}$ or sulfo-Mont ions).

To our knowledge oxo- $\mathrm{W}^{5+}$ ions on supported tungsten catalysts have not been previously reported in the literature. The behavior of signal I on the supported tungsten catalysts is analogous to that on the corresponding molybdenum samples, leading to the conclusion that this signal for the tungsten system has to be ascribed to oxo- $W^{5+}$ ions. The intensity of the oxo$\mathrm{W}^{5+}$ ion signal is lower than that of the oxo- $\mathrm{Mo}^{5+}$ signal obtained under the same sulfiding conditions. It is therefore possible that the interaction of tungsten with the supports is lower than that of molybdenum or that under the same experimental conditions the supported tungsten samples are better sulfided in comparison to the molybdenum samples. The diminution of the oxo- $\mathrm{Mo}^{5+}$ signals as a resulc of evacuation 
is probably caused by a reduction in valency of the metal as a consequence of removal via desorption of coordinated ligands. Such oxidic species are thought to be responsible for part of the hydrogenation activity of $\gamma-\mathrm{Al}_{2} \mathrm{O}_{3}$-supported Co-Mo and Ni-W catalysts (20).

The ESR spectra obtained by Seshadri et al. (23) and Lo Jacono et al. (24) after sulfiding of $\gamma-\mathrm{Al}_{2} \mathrm{O}_{3}$-supported molybdenum catalyst showed only the presence of oxo$\mathrm{Mo}^{5+}$ and the $3 \mathrm{~g}$-value signal, which has been ascribed in the literature to $S_{n} \cdot(25)$ or $S_{2} \cdot(26)$. Lo Jacono et al. (24) reported an increase in this $3 g$-value signal after oxygen treatment at higher temperatures. From our results presented in Fig. $4 \mathrm{~d}$ it can be concluded that the presence of oxygen inhibits the detection of ESR signals of types II, IV, and $V$ on supported molybdenum samples. The ESR results obtained in this work on sulfided supported and unsupported molybdenum and tungsten samples show that type II, IV, and V signals are detected on all samples. Since the bulk samples are disulfides it is very likely that the disulfide phase is also present on the supported catalyst after sulfidation.

Signal III is only detected on supported molybdenum catalysts after $\mathrm{H}_{2} \mathrm{~S}$ or thiophene treatment. Kolosov et al. (27) reported an ESR signal on a $\mathrm{Mo} / \mathrm{SiO}_{2}$ sample $\left[3 \%(\mathrm{w} / \mathrm{w}) \mathrm{MoO}_{3}\right]$, which corresponds with the ESR spectrum shown in Fig. 7b. Their Mo/SiO ${ }_{2}$ sample, which initially was oxidic, was slightly reduced with $\mathrm{H}_{2}$ at $500^{\circ} \mathrm{C}$ and then treated with $\mathrm{H}_{2} \mathrm{~S}$ vapor at $500^{\circ} \mathrm{C}$ for several minutes. The authors interpreted the ESR spectrum as a $2 g$-value signal. Our results (comparison of spectra in Figs. $7 \mathrm{~b}$ and $\mathrm{c}$ ) show that the signal is a superposition of peaks II and III. More experiments are needed to find out from which phase signal III originates (oxo-sulfo- or sulfo-molybdenum ions).
The disulfide phase is probably stoichiometrically best defined after the evacuation treatment, since the normal sulfiding conditions employed in this work will almost certainly result in surfaces partly covered by adsorbed $\mathrm{H}_{2} \mathrm{~S}$. Changes in the ESR signals II and IV as a result of this treatment can therefore most reasonably be ascribed to the participation of surface species. Signal IV is the most intense in the evacuated samples. Voorhoeve (1) reported a $\mathrm{W}^{3+}$ ESR signal detected on sulfided tungsten-containing catalyst. Moreover, he proved that this signal arises from paramagnetic surface species. A comparison of the ESR parameters ( $g$ value and linewidth) of the $\mathrm{W}^{3+}$ signal found by Voorhoeve after equilibration $\left(10^{-5}<\mathrm{H}_{2} \mathrm{~S} / \mathrm{H}_{2}\right.$ $<10^{-3}$ ) of $\mathrm{WS}_{2}$ samples with the $g$ value $(g \simeq 2.012)$ and linewidth $(\Delta H \simeq 180 \mathrm{G})$ of signal IV obtained in this work, after evacuation of the $\mathrm{WS}_{2}$ bulk sample, leads to the conclusion that signal IV is most probably related to trivalent paramagnetic surface ions $\left(\mathrm{M}_{\mathrm{s}}{ }^{3+}\right)$. The decrease in intensity of this signal after sulfidation is accompanied by an increase in the intensity of signal II (compare the evacuated and sulfided samples in Figs. 5 and 6).

As mentioned earlier, the normal sulfiding conditions employed in this work might lead to adsorption of $\mathrm{S}$ and or $\mathrm{SH}$ species. Here several possibilities suggest themselves. The change in $g$ value upon $\mathrm{H}_{2} \mathrm{~S}$ adsorption (i.e., peak IV $\rightarrow$ II) could be a consequence of a change in coordination of the same ion in the same valence state,

$$
\mathrm{S}_{x} \mathrm{M}_{\mathrm{s}}{ }^{3+}+\mathrm{H}_{2} \mathrm{~S} \rightleftharpoons \mathrm{S}_{x-1} \mathrm{M}_{\mathrm{s}}{ }^{3+}(\mathrm{SH})_{2},
$$

or a change in valence state of one or more surface ions,

$$
\mathrm{M}_{\mathrm{s}}{ }^{3+} \square+\mathrm{H}_{2} \mathrm{~S} \rightleftharpoons \mathrm{M}_{\mathrm{s}}{ }^{5+} \mathrm{S}^{2-}+\mathrm{H}_{2} .
$$

Both of these processes result in retention of the number of paramagnetic surface species. 


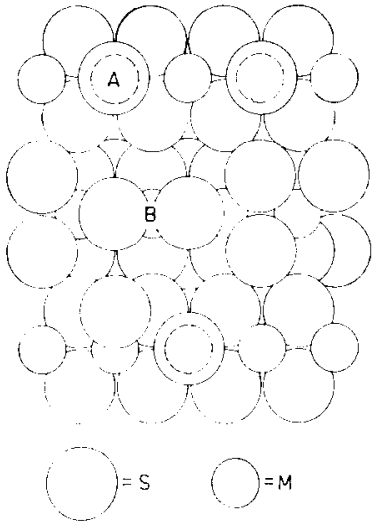

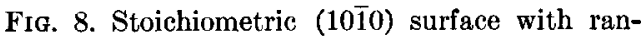
domly oriented sulfur.

The number of paramagnetic surface species decreases consequently upon adsorption when the following equilibrium occurs :

$$
\begin{aligned}
& \mathrm{M}_{\mathrm{s}}{ }^{3+-} \square-\mathrm{M}_{\mathrm{B}}{ }^{3+}+\mathrm{H}_{2} \mathrm{~S} \rightleftharpoons \\
& \mathrm{M}_{\mathrm{s}}{ }^{4+}-\mathrm{S}^{2-}-\mathrm{M}_{\mathrm{s}}{ }^{4+}+\mathrm{H}_{2} .
\end{aligned}
$$

It is of interest to attempt a description of the different possible paramagnetic sites occurring on the surface of $\mathrm{MS}_{2}$ crystallites based on structural details of the $\mathrm{MS}_{2}$ phase. $\mathbf{M S}_{2}$ has a layer structure in which $\mathrm{Mo} / \mathrm{W}$ is trigonal, prismatically surrounded by $\mathrm{S}(\mathcal{2}-4)$. Under industrial operating conditions the hexagonal $2 \mathrm{H}-\mathrm{MS}_{2}$ modification is the thermodynamically stable one. The edges of the basal planes expose incompletely coordinated metal ions, which are the most likely seat of catalytic activity. Large crystals of hexagonal $\mathrm{MS}_{2}$ form

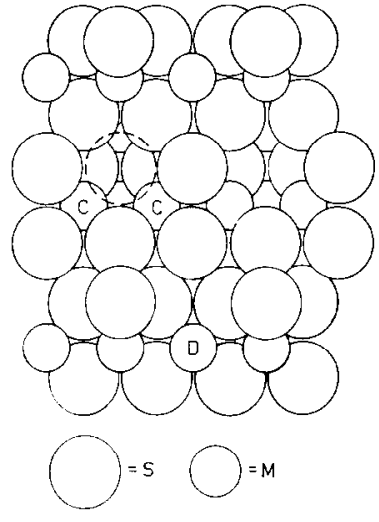

FIG. 9. Stoichiometric $(10 \overline{1} 0)$ surface with randomly oriented sulfur.

(1010) edges. Alternate layers in these edges expose anions which are bridging or nonbridging, respectively (28). These surfaces are degenerate, since to a first approximation the anion may occupy other equivalent sites without appreciably altering the surface energy. In Figs. 8 and 9

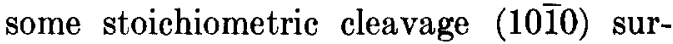
faces with randomly oriented surface sulfur atoms are shown (28). Several different surface species can be distinguished. Site D is four-coordinate, has a formal charge $z=+2 \frac{2}{3}$ and has $C_{4 \mathrm{v}}$ symmetry. Site $B$ is also four-coordinate, has formal charge $z=+3 \frac{1}{3}$ and $C_{2 \mathrm{v}}$ symmetry.

Adsorption of a sulfur atom may convert the four-coordinate site $\mathrm{D}$ to a fivecoordinate site A (formal valence state $+4 \frac{2}{3}, C_{4 \mathrm{v}}$ symmetry). Adsorption of sulfur shown dotted in Fig. 9 creates from the initial five-coordinate site $\left(z=+4 \frac{1}{3}, C_{s}\right.$

TABLE 2

\begin{tabular}{|c|c|c|c|c|c|c|}
\hline \multirow[t]{2}{*}{ Signal } & \multicolumn{3}{|c|}{ Molybdenum } & \multicolumn{3}{|c|}{ Tungsten } \\
\hline & Compound & $g$ & $\Delta H$ & Compound & $g$ & $\Delta H$ \\
\hline $\mathbf{I}$ & $\mathrm{Mo} / \gamma-\mathrm{Al}_{2} \mathrm{O}_{3}$ & 1.933 & 80 & $\mathrm{~W} / \gamma-\mathrm{Al}_{2} \mathrm{O}_{3}$ & 1.78 & 130 \\
\hline II & $\mathrm{Mo} / \mathrm{SiO}_{2}$ & 1.985 & 38 & $\mathrm{~W} / \gamma-\mathrm{Al}_{2} \mathrm{O}_{3}$ & 1.91 & 100 \\
\hline IV & $\mathrm{Mo} / \gamma-\mathrm{Al}_{2} \mathrm{O}_{3}$ & 1.995 & 68 & $\mathrm{WS}_{2}$ & 2.01 & 180 \\
\hline
\end{tabular}

ESR Parameters of Signals I, II, and IV 
symmetry) two paramagnetic type $\mathrm{C}$ sites $\left(z=+5 \frac{1}{3}, C_{2 \mathrm{v}}\right.$ symmetry):

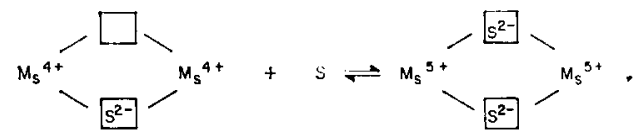

Adsorption of $\mathrm{H}_{2} \mathrm{~S}$ in place of sulfur would lead to retention of the formal charge and no ESR signal:

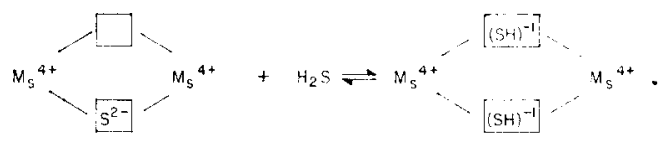

Inspection of Figs. 8 and 9 shows many other variants of these processes to be possible.

The linewidth of signal II is smaller than that of signal IV (see Table 2). This might be caused by an exchange-narrowing process which in turn could arise if type $C$ sites were the major contributors to signal II. Signal IV seems to have the shape of a $2 g$-value ESR signal [see Figs. 5b (W) and $6 \mathrm{~b}$ (Mo)], which corresponds with the symmetry properties of site D or B. Since this signal can be detected at room temperature the spin-lattice relaxation must be negligible, which occurs in situations with a nondegenerate orbital ground state and weak spin-orbit interactions with orbitals of higher and lower energy. Examples of paramagnetic Mo or $\mathrm{W}$ ions with $d^{3}$ and $S=\frac{1}{2}$ are seldom reported in the literature, although Rossman et al. (29) have found evidence for a $\mathrm{Mo}^{3+}$ ion $\left(d^{3}\right.$, $\left.S=\frac{1}{2}\right)$ observed for solid $\mathrm{K}_{4} \mathrm{Mo}(\mathrm{CN})_{7}$ $\cdot 2 \mathrm{H}_{2} \mathrm{O}$ at $77^{\circ} \mathrm{K}\left(g_{\| 1}=2.103\right.$ and $g_{x} \simeq g_{y}$ $=1.973$ ).

The sharp ESR signals, which are sometimes superimposed on the ESR spectra (Fig. 5b: $g=2.005$; Fig. 6e: $g=2.003$ ) are probably caused by contamination (grease) of the ESR samples. These signals will be further investigated.

From hydrogenation and hydrodesulfurization experiments several authors (3034) have suggested the existence of two different kinds of active sites in $\mathrm{Co} / \mathrm{Ni}-$ Mo/W sulfide catalysts. The fact that $\mathrm{H}_{2} \mathrm{~S}$ adsorption is found to inhibit hydrogenation as well as HDS reactions, combined with our finding that this adsorption influences our ESR signals (II and IV), suggests a correlation between the existence of type $A$ and $D$ sites with the catalytic properties of the catalysts mentioned above.

In summary this work has demonstrated the existence of five ESR signals in sulfided molybdenum and tungsten catalysts. One of these (signal I) arises as a result of interactions with the support, and another (signal III) may have a similar origin. Two signals (II and IV) show a complementary behavior upon evacuation and $\mathrm{H}_{2} \mathrm{~S}$ adsorption and therefore appear to be related to surface species of the $\mathrm{MS}_{2}$ phase and possibly its catalytic properties. The origin of the remaining signal ( $V$ ) is unknown.

Work is in progress on the quantitative relationship between the changes in the signals and the $\mathrm{H}_{2} \mathrm{~S} / \mathrm{H}_{2}$ ratios in contact with the catalysts. The influence of $\mathrm{Ni}$ and Co promoters is also under investigation.

\section{REFERENCES}

1. Voorhoeve, R. J. H., J. Catal. 23, 236 (1971).

2. Farragher, A. L, and Cossee, P., in "Proceedings, Fifth International Congress on Catalysis" (J. W. Hightower, Ed.), p. 1301. North-Holland, Amsterdam, 1973.

3. Jellinek, F., in "Inorganic Sulphur Chemistry" (G. Nickless, Fd.), p. 669. Elsevier, Amsterdam, 1968.

4. Huisman, R., De Jonge, J., Haas, C., and Jellinek, F., J. Solid State Chem. 3, 56 (1971).

5. Ahuja, S. P., Derrien, M. L., and Le Page, J. F., Ind. Eng. Chem. 9, 272 (1970).

6. Urimoto, H., and Sakikawa, N., Sekiyu Gakkai Shi 15, 926 (1972).

\%. Furimsky, E., and Amberg, C. H., Canad. J. Chem. 54, 1507 (1976).

8. De Beer, V. H. J., Van Sint Fiet, T. H. M., Van der Steen, G. H. A. M., Zwaga, A. C., and Schuit, G. C. A., J. Catal. 35, 297 (1974).

9. Méring, J., and Lévialdi, A., C.R. Acad. Sci. Paris 213, 798 (1941).

10. Voorhoeve, R. J. H., and Wolters, H. B. M., Z. Anorg. Allg. Chem. 376, 165 (1970). 
11. Corleis, E., Lieb. Ann. 232, 259 (1886).

12. Berzelius, J. J., Pogg. Ann. 7, 270 (1826).

13. De Beer, V. H. J., Van Sint Fiet, T. H. M., Engelen, J. F., Van Haandel, A. C., Wolfs, M. W. J., Amberg, C. H., and Schuit, G. C. A., J. Catal. 27, 357 (1972).

14. Peacock, J. M., Sharp, M. J., Parker, A. J., Ashmore, P. G., and Hockey, J. A., J. Catal. 15, 379 (1969).

15. Burlamacchi, L., Martini, G., and Ferroni, E., Trans. Faraday Soc. 68, 1586 (1972).

16. Abdo, S., Lo Jacono, M., Clarkson, R. B., and Hall, W. K., J. Catal. 36, 330 (1975).

17. De Beer, V. H. J., and Schuit, G. C. A., in "Preparation of Catalysts" (B. Delmon, P. A. Jacobs, and G. Poncelet, Eds.), p. 343. Elsevier, Amsterdam, 1976.

18. Giordano, N., Bart, J. C. J., Vaghi, A., Castellan, A., and Martinotti, G., J. Catal. 36, 81 (1975).

19. Giordano, N., Castellan, A., Bart, J. C. J., Vaghi, A., and Campadelli, F., J. Catal. 37, 204 (1975).

20. De Beer, V. H. J., Van der Aalst, M. J. M., Machiels, C. J., and Schuit, G. C. A., J. Catal. 43, 78 (1976).

21. Ueda, H., Todo, N., and Kurita, M., J. LessCommon Metals 36, 387 (1974).

22. Che, M., Figueras, F., Forissier, M., MeAteer, J., Perrin, M., Portefaix, J. L., and Praliaud, H., in "Proceedings, Sixth International
Congress on Catalysis" (London, 1976), p. 261. Chemical Society, London, 1977.

23. Seshadri, K. S., Massoth, F. E, and Petrakis, L., J. Catal. 19, 95 (1970).

24. Lo Jacono, M., Verbeek, J. L., and Schuit, G. C. A., in "Proceedings, Fifth International Congress on Catalysis" (J. W. Hightower, Ed.), p. 1409. North-Holland, Amsterdam, 1973.

25. Dudzik, Z., and Preston, F. K., J. Colloid Interface Sci. 26, 374 (1968).

26. Kolosov, A.K., Shvets, V. A., Chuvylkin, N. D., and Kazansky, V. B., J. Catal. 47, 190 (1977).

27. Kolosov, A. K., Shvets, V. A., and Kazansky, V. B., Kinet. Catal. 16, 161 (1975).

28. Farragher, A. L., in "Symposium on the Role of Solid State Chemistry in Catalysis," American Chemical Society Meeting, New Orleans, March 1977. Petroleum Division preprint.

29. Rossman, G. R., Tsay, F. D., and Gray, H. B., Inorg. Chem. 12, 824 (1973).

30. Voorhoeve, R. J. H., and Stuiver, J. C. M., J. Catal. 23, 243 (1971).

31. Stevens, G. C., and Edmonds, T., J. LessCommon Metals 54, 321 (1977).

32. Desikan, P., and Amberg, C. H., J. Canad. Chem. 42, 843 (1964).

33. Tanaka, K., Okuhara, T., Sato, S., and Miyahara, K., J. Catal. 43, 360 (1976).

34. Hagenbach, G., Courty, P., and Delmon, B., J. Catal. 31, 264 (1973). 